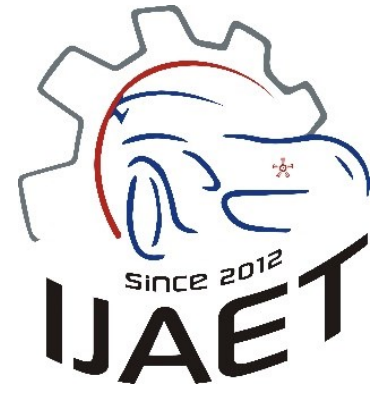

e-ISSN: 2146 - 9067

International Journal of Automotive

Engineering and Technologies

journal homepage:

https://dergipark.org.tr/en/pub/ijaet

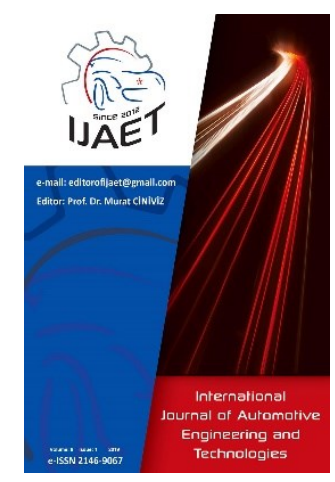

Original Research Article

\title{
Combustion, performance and emission caracteristics of a HCCI engine fuelled with $\mathbf{n}-b_{\text {butanol} / \mathbf{n}-h e p t a n e}$ blends
}

\author{
Bilal Aydoğan",*, Alper Calam² \\ 1,* Burdur Mehmet Akif Ersoy University, High Vocational School of Technical Sciences, 15100 Burdur, Turkey \\ ${ }^{2}$ Gazi University, High Vocational School of Technical Sciences, 06760, ANKARA, Turkey
}

\section{ARTICLE INFO}

* Corresponding author

baydogan@mehmetakif.edu.tr

Received: July 18, 2019

Accepted: Dec 19, 2019

Published by Editorial Board Members of IJAET

(C) This article is distributed by Turk Journal Park System under the CC 4.0 terms and conditions.

\begin{abstract}
Homegeneous charge compression ignition (HCCI) combustion can achieve very low $\mathrm{NO}_{\mathrm{x}}$ and soot emissions but knocking and misfiring restrict the operating range of this kind of engines. In this work, n-butanol which has low reactivity and high volatility blended with n-heptane that choosen as reference fuel in this study with various rates $(25 \mathrm{vol} \%$ and 50 vol\%). The experiments performed at various engine speeds (800-1800) and lambda $(\lambda=1.6-2.95)$ at full load and $60{ }^{\circ} \mathrm{C}$ inlet air temperature. the parameters such as in-cylinder pressure, heat release rate, CA10, ringing intensity, thermal efficiency, brake torque, power output, specific fuel consumption, and $\mathrm{HC}$ and $\mathrm{CO}$ emissions were determined. The results showed that both in-cylinder pressure and heat release rate decreased with increasing lambda. Increasing amount of n-butanol in the charge mixture resulted a decrease both in-cylinder pressure and heat release rate. $\mathrm{n}$ butanol also provided retarded combustion phasing and increased CA10. Ringing intensity decreased with increasing both lambda and n-butanol content in the mixture. Thermal efficiency increased with n-butanol. HC and $\mathrm{CO}$ emissions increased with increasing lambda. $\mathrm{HC}$ and $\mathrm{CO}$ emissions increased with increasing amount of n-butanol in the charge mixture. Operating range of HCCI engine was expanded with n-butanol in both knocking and misfiring zones.
\end{abstract}

Keywords: HCCI, n-butanol, combustion, n-heptane

\section{Introduction}

Petroleum based fuels are widely used in many fields such as transportation sector in the world. With the development of technology, the use and consumption of fossil fuels, however, the damage to the environment and the atmosphere is increasing day by day. Especially strict limitations of the environmental pollution has canalized the researchers to different engine and combustion techniques [1]. The gas temperature at the end of the combustion increases at high loads and rich mixtures and NO generation occurs. At the same time, locally rich mixture areas occurs due to the heteregoneous mixture in the combustion chamber and $\mathrm{HC}$ and smoke generate. Homogenous charge compression 
ignition (HCCI) engines have high efficiency due to high compressions ratio and a shorter combustion duration and ultra low $\mathrm{NO}_{\mathrm{x}}$ emissions owing to low combustion temperatures [2-6]. Furthermore, HCCI engines have less soot and particulate matter than SI and diesel engines because lean and homogenous air/fuel mixture is taken into the cylinder [7-9]. Despite all these advantages, ignition can not be controlled directly and autoignition is controlled by chemical kinetics of the fuel [10-12]. Besides, the operating of HCCI engines is restricted by knocking and misfiring [13-15]. Several studies has been performed by many researchers to eliminate these disadvantages and various methods have been proposed like EGR (exhaust gas recirculation) [16-18], changing valve lift $[19,20]$, changing inlet air temperature [21, 22], changing compression ratio [23], using different fuels [24-26]. HCCI engines have also fuel flexibility such as diesel, gasoline, natural gas and some alcohols [27-29]. Various alcohols including ethanol [30, 31], methanol [32-33], diethyl ether [34-35] and others [36-37] have been used and blended with primary reference fuels, isopropanol and n-heptane in HCCI engines.

Butanol is renewable fuel that have various advantages for internal combustion engines. Butanol can be obtained from the fermantation of the biomass feedstock. Butanol in diesel and HCCI engines has been examined as a blend with different fuels. He et al [38] investigated the effects of n-butanol and blends with gasoline on combustion and emission characteristics of a single cylinder port fuel injection four-stroke HCCI/CAI engine. They have reported that autoignition occured earlier and combustion duration was shortened when the amount of nbutanol increased in the mixture. Furthermore, imep decreased when the engine speed and nbutanol was increased. Li et al [39] searched the effects of n-butanol/n-heptane blends on knock tendency and cyclical variations of a HCCI combustion oporation conducted 2 nd cylinder of a natural aspirated four stroke diesel engine. The experiments showed that knock tendency decreased with increasing of n-butanol volume fraction. Higher heat release rate which cause knock tendency was obtained when engine speed and intake temperature increased. Liu et al [40] investigated the effect of air dilution and effective compression ratio on the combustion characteristics of a single cylinder four-stroke HCCI engine fuelled with n-butanol. It was found that autoignition timing was retarded by air dilution and decreasing effective compression ratio. However, air dilution caused reduced maximum pressure rise rate and increased combustion duration. Zheng et al [41] studied the effects of n-butanol in a HCCI combustion mode. They performed their experiments on a single-cylinder high compression ratio (18.2:1) diesel engine without any modifications. The results showed that ultra-low $\mathrm{NO}_{\mathrm{x}}$ and smoke emissions were observed with n-butanol. N-butanol with low reactivity helped in realizing an optimal combustion phasing. Mack et al [42] investigated of n-butanol and isobutanol combustion in HCCI engine. N-butanol showed slightly more stable engine operation and misfiring occured under very lean conditions. Higher heat release rate was observed at the begining of combustion. N-butanol has lower knocking resistane compared to isobutanol, gasoline and ethanol. The emissions of $\mathrm{n}$ butanol and isobutanol are in the same range as ethanol and gasoline. He et al [43] studied the combustion of n-butanol/ethanol-gasoline blends in a HCCI engine. They used a single cylinder port fuel injection gasoline engine. They have reported that alcohol type and the concentration of the alcohol are the main parameters which effect the autoignition timing. The alcohol and gasoline blends autoignitied more easily than gasoline and the autoignition timing was earlier than ethanol-gasoline for nbutanol-gasoline blends.

In this study, the effects of n-butanol/n-heptane blends on combustion, performance and emission characteristics on a HCCI engine and the results were compared with pure n-heptane. The combustion parameters such as in-cylinder pressure, heat release rate, CA10, combustion duration, ringing intensity, thermal efficiency, power output, brake torque, specific fuel consumption, and $\mathrm{HC}$ and $\mathrm{CO}$ emissions were determined. And the operating range of HCCI combustion was also obtained.

\section{Materials and Methods}

A single cylinder, port injection, four stroke gasoline HCCI engine was used to perform 
experiments. The technical properties of the test engine was given in Table 1 and the schematic diagram of the experimental setup was given in Figure 1. DC dynamometer which was rated 30 $\mathrm{kW} / 6500 \mathrm{rpm}$ engine speed was conducted to the engine. The experiments were performed at range of 800-1800 rpm engine speed and $\lambda=1.61$ and $\lambda=2.95$. K-type thermocouple was used to measure temperatures.

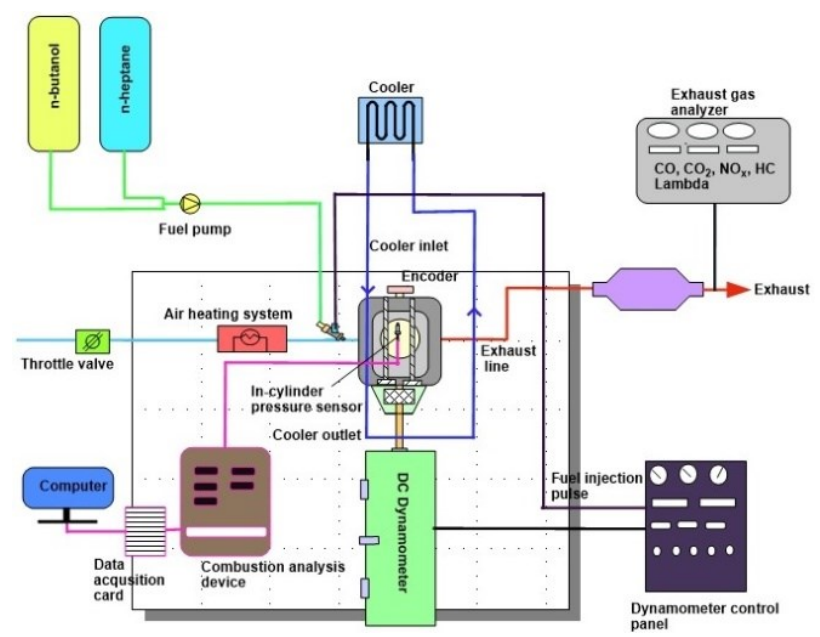

Figure 1. The shematic diagram of the experimental setup

Table 1. The technical properties of the test engine

\begin{tabular}{ll}
\hline Model & Ricardo-Hydra \\
\hline Number of Cylinders & 1 \\
Cylinder bore (mm) & 80.26 \\
Stroke (mm) & 88.90 \\
Volume (cc) & 540 \\
Compression ratio & $13: 1$ \\
Power output (kW) & 15 \\
Maximum engine speed & 5400 \\
(rpm) & IVO/EVC \\
Valve timing & BTDC/56 ATDC $16^{\circ}$ \\
Valve lift & Intake/exhaust 5.5/3.5 \\
\hline
\end{tabular}

In-cylinder pressure was measured with Kristler model 6121 piezoelectric pressure transducer. Pressure data was scaled up by Cussons P4110 combustion analysis device. The data was converted to digital signals by National Instruments USB 6259 data acquisition card. The pressure data of the cylinder were recorded in the computer. $\mathrm{HC}, \mathrm{CO}, \mathrm{NO}$ emissions and air/fuel ratio was measured with exhaust gas analyzer.

n-butanol/n-heptane blends (25BUT75HEP, 50BUT50HEP) and n-heptane (100HEP) were used in the experiments. The chemical properties of the fuels were given in Table 2 . The abbreviations of the test fuels were given at Table 3. The technical properties of the exhaust gas analyzer and cylinder pressure transducer were given at Table 4 and 5, respectively. The measurement equipments are calibrated as periodically.

Table 2. Chemical properties of the test fuels [44]

\begin{tabular}{lll}
\hline & n-Butanol & n-Heptane \\
\hline Chemical Formula & $\mathrm{C}_{4} \mathrm{H}_{10} \mathrm{O}$ & $\mathrm{C}_{7} \mathrm{H}_{16}$ \\
Density $\left(\mathrm{kg} / \mathrm{m}^{3}\right)$ & 808 & 679.5 \\
$\begin{array}{l}\text { Octane number } \\
\text { Lower heating value } \\
(\mathrm{MJ} / \mathrm{kg})\end{array}$ & 35.1 & 0 \\
Boiling point $\left({ }^{\circ} \mathrm{C}\right)$ & 117.7 & 44.56 \\
Molar mass $(\mathrm{g} / \mathrm{mol})$ & 74.12 & 98 \\
\hline
\end{tabular}

Imep was calculated by dividing net work and cylinder swept volume (Eq. (1)) and the net work was obtained by Eq. (2). Heat release rate was calculated by Eq. (3).

Table 3. Percentage of fuels and abbreviations

\begin{tabular}{ccc}
\hline Abbreviation & $\begin{array}{c}\text { n-heptane } \\
(\mathbf{\%})\end{array}$ & n-butanol (\%) \\
\hline 100HEP & 100 & - \\
25BUT75HEP & 75 & 25 \\
50BUT50HEP & 50 & 50 \\
\hline
\end{tabular}

Table 4. The technical specifications of the exhaust gas analyzer

\begin{tabular}{|c|c|c|c|}
\hline $\begin{array}{l}\text { Exhaust } \\
\text { analyzer }\end{array}$ & gas & Operating range & Accuracy \\
\hline $\mathrm{CO}(\%)$ & & $0-15$ & 0.001 \\
\hline NO (ppm) & & 0-9999 & $1 \mathrm{ppm}$ \\
\hline $\mathrm{HC}(\mathrm{ppm})$ & & $0-5000$ & $1 \mathrm{ppm}$ \\
\hline $\mathrm{O}_{2}(\%)$ & & $0-20$ & 0.01 \\
\hline $\mathrm{CO}_{2}(\%)$ & & $0-25$ & 0.1 \\
\hline Lambda & & $0.6-4$ & 0.001 \\
\hline
\end{tabular}

Table 5. Technical properties of the cylinder pressure transducer

\begin{tabular}{lc}
\hline \multicolumn{1}{c}{ Model } & $\begin{array}{c}\text { Kistler 6121 piezo } \\
\text { electric }\end{array}$ \\
\hline $\begin{array}{l}\text { Operating range (bar) } \\
\text { Measurement precision }\end{array}$ & $0-250$ \\
(pC/bar) & 14.7 \\
Operating temperature $\left({ }^{\circ} \mathrm{C}\right)$ & $-50-350$ \\
Accuracy $( \pm \%)$ & 0.5 \\
\hline$i m e p=\frac{W_{\text {net }}}{V_{d}}$ & $(1)$ \\
$W_{\text {net }}=\int P d V$ \\
$\frac{d Q}{d \theta}=\frac{k}{k-1} P \frac{d V}{d \theta}+\frac{1}{k-1} V \frac{d P}{d \theta}+\frac{d Q_{\text {heat }}}{d \theta}$
\end{tabular}

Thermal efficiency calculated with the ratio between the net work and released energy from fuel (Eq. (4)).

$\eta_{T}=\frac{W_{\text {net }}}{m_{\text {fuel } 1} \cdot Q_{L H V 1}+m_{\text {fuel2 } 2} \cdot Q_{L H V 2}}$ 


\section{Results and Discussion}

Figure 2. shows the variation of in-cylinder pressure and heat release rate of the test fuels versus crank angle at $1000 \mathrm{rpm}$ engine speed and $60{ }^{\circ} \mathrm{C}$ inlet air temperature. n-heptane was used as base fuel in the experiments. It is clearly seen that knocking combustion occured with nheptane at lower value of the lambda. Knocking combustion disaappeared when the n-butanol was added in the charge mixture owing to higher octane number of n-butanol. In other words, more stable HCCI combustion occured. When the Figure 2 was examined, it is possible to say that heat release rate significantly decreased when the amount of $n$-butanol increased.
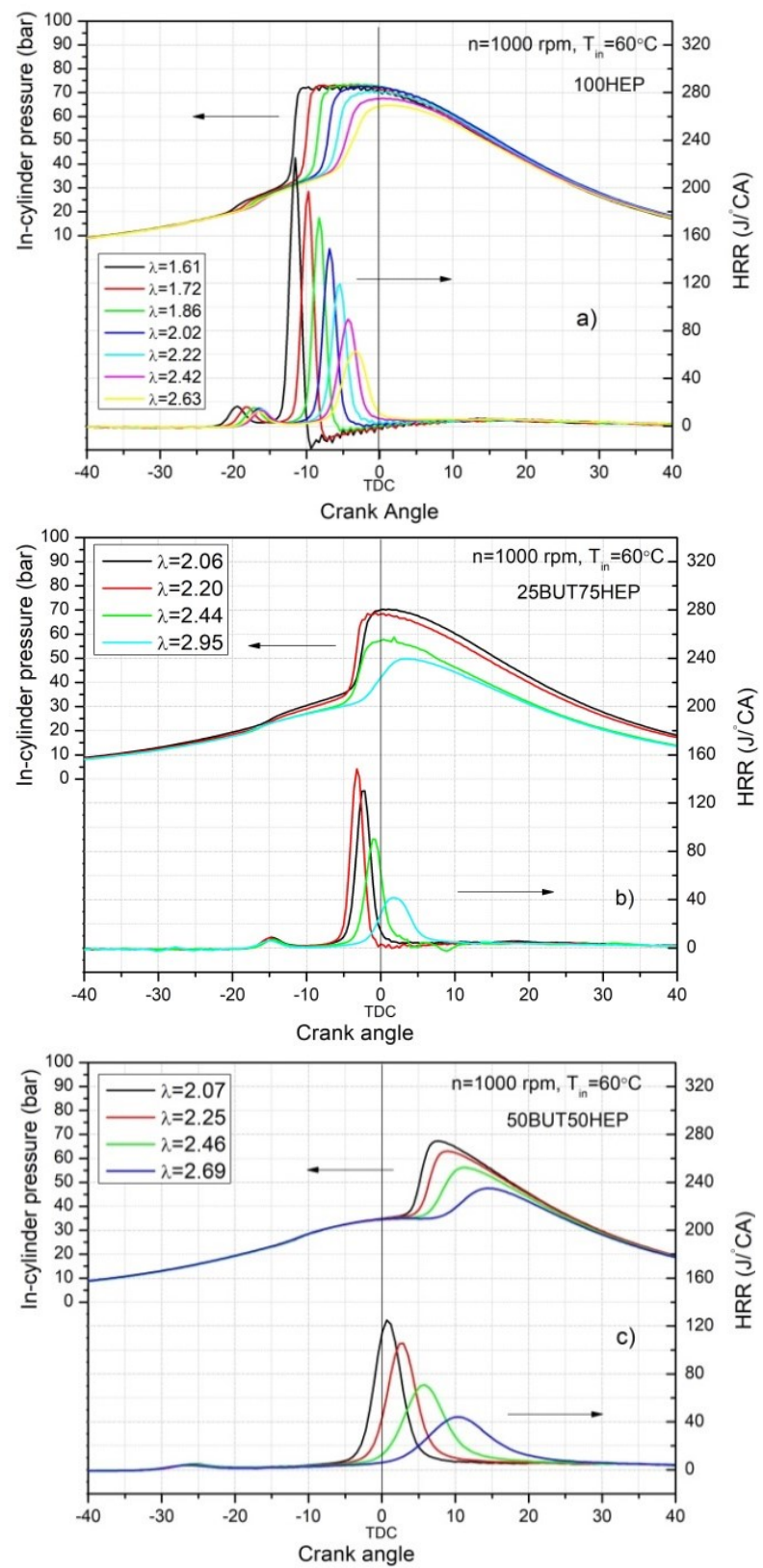

Figure 2. The variations of in-cylinder pressure and heat release rate of a) n-heptane b) 25\% n-butanol/75\% nheptane and c) $50 \%$ n-butanol $/ 50 \%$ n-heptane.
Combustion phasing retarded when the lambda was increased. As it can be clearly seen from the Figure 2 that HCCI combustion was achieved closer to dead top center when the amount of nbutanol increased in the mixture due to higher octane number which increased the resistance to auto-ignition. Furthermore, both in-cylinder pressure and heat release rate increased by decreasing the value of lambda. It is because the higher charge concentration increases the reaction rate and accelerates the heat release progress resulting in increase of maximum pressure.

Figure 3 illustrates the variations of CA10 versus lambda. CA10 is defined as the crank angle where the $10 \%$ mass fraction burned [45]. Start of combustion (SOC) can also be defined by CA10. Combustion phasing was advanced with the increase of lambda for all test fuels. The CA10 value of n-heptane was determined as $6.58^{\circ} \mathrm{CA}$ BTDC for $\lambda=2.4$. However, CA10 was found as $1.8^{\circ} \mathrm{CA}$ BTDC and $5.76^{\circ} \mathrm{CA}$ ATDC for 25BUT75HEP and 50BUT50HEP, respectively, for $\lambda=2.4$. It is seen that autoigniton was retarded with increasing the lambda owing to lower fraction of fuel at leaner charge mixture.

The effect of n-butanol addition at $1000 \mathrm{rpm}$ engine speed and $60{ }^{\circ} \mathrm{C}$ inlet air temperature versus lambda was given in Figure 4. Ringing intensity is an important parameter which limits the operating range of HCCI combustion [46].

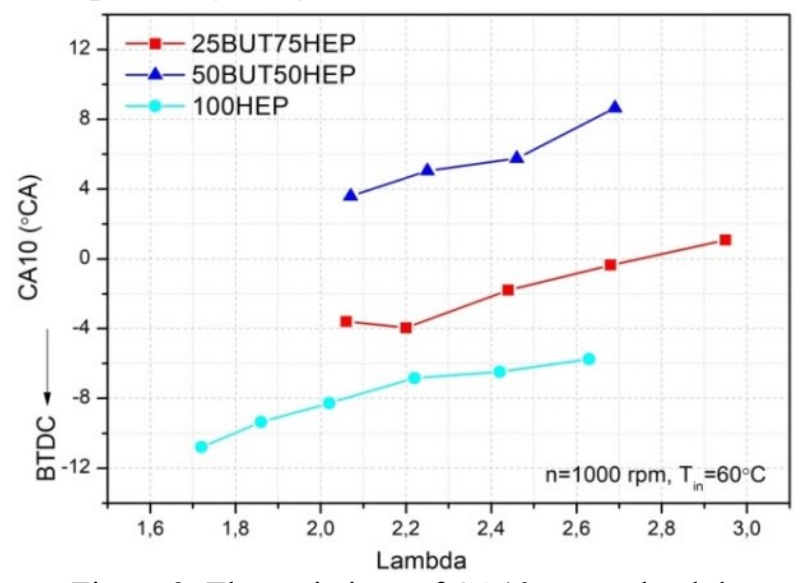

Figure 3. The variations of CA10 versus lambda

Engine speed, maximum in-cylinder pressure and combustion rate are the major parameters which effect the ringing intensity [47]. It can be clearly seen from the Figure 4 . that ringing intensity decreased with increasing lambda. As it was mentioned before that knocking combustion reduced in leaner charge mixture 
and thereby combustion noise decreased. In the other words, ringing intensity decreased with leaner charge mixture. Ringing intensity decreased also with increasing amount of nbutanol in the charge mixture due to higher octane number of n-butanol that that of nheptane. The lowest value of ringing intensity was obtained for 50BUT50HEP.

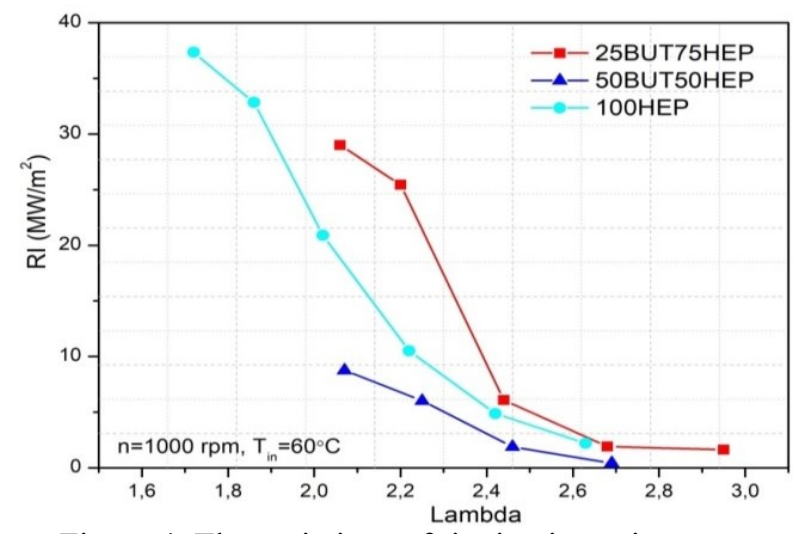

Figure 4. The variations of ringing intensity versus lambda

The variations of brake torque, power output and specific fuel consumption versus engine speed was given in Figure 5. Power output increased with increasing the engine speed and then decreased after a specific value. This decrease depends on the friction losses and insufficient oxygen at high engine speeds. The maximum power output was found as $0.56 \mathrm{~kW}$ for $n$-heptane at $1400 \mathrm{rpm}$ engine speed. The corresponding value was $0.89 \mathrm{~kW}$ for 50BUT50HEP at $1200 \mathrm{rpm}$ engine speed. Brake torque similarly increased to until a specific value and then decreased. It can be explained with gas leakages and heat losses occurred at high engine speeds. 50BUT50HEP showed higher power output and brake torque than the other test fuels. Lower power output and brake torque was obtained for n-heptane for each engine speed. the maximum brake torque was obtained as $7.15 \mathrm{Nm}$ for 50BUT50HEP at 1200 rpm engine speed. When Figure 5 was examined, it is possible to say that specific fuel consumption firstly decreased and then increased unlike power output and brake torque. SFC was found as $0.24,0.42$ and $0.54 \mathrm{~kg} / \mathrm{kWh}$ for 25BUT75HEP, 50BUT50HEP and 100HEP, respectively.

The effect of test fuels on thermal efficiency was given in Figure 6. Thermal efficiency firstly increased and then started to decrease. The maximum values of thermal efficiency were obtained as $48 \%, \quad 32 \%$ and $27 \%$ for 25BUT75HEP, 50BUT50HEP and 100HEP, respectively. The corresponding maximum values were found at $\lambda=2.68, \lambda=2.46$ and $\lambda=2.42$ where the whole fuel molecules can be reacted and oxidized for 25BUT75HEP, 50BUT50HEP and $100 \mathrm{HEP}$, respectively.
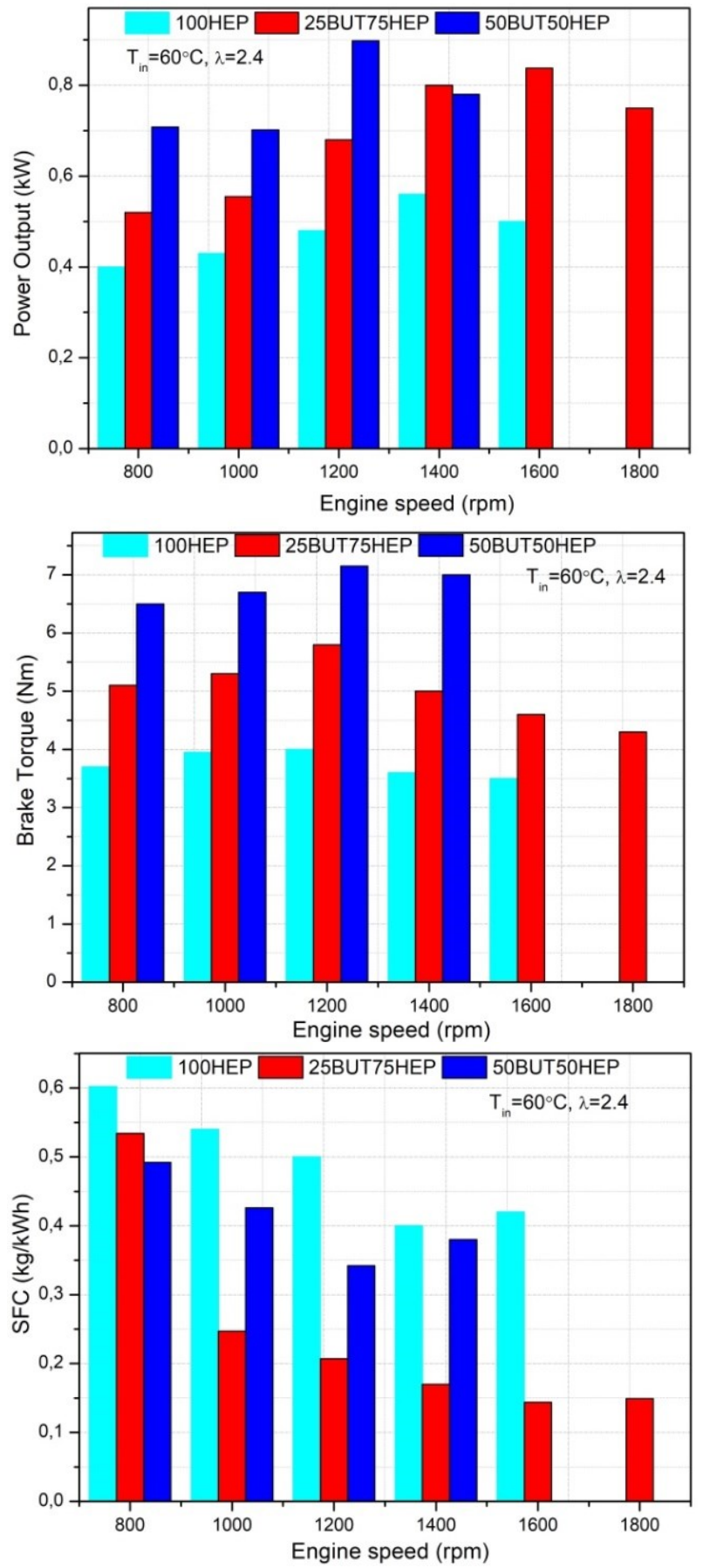

Figure 5. The variations of brake torque, power output and specific fuel consumption

The corresponding maximum values were found at $\lambda=2.68, \lambda=2.46$ and $\lambda=2.42$ where the whole fuel molecules can be reacted and oxidized for 25BUT75HEP, 50BUT50HEP and 100HEP, 
respectively. Released heat energy decreased at leaner charge mixture resulting decrease in thermal efficiency. The maximum value of thermal efficiency was found for 25BUT75HEP. Higher density and considerable calorific value of n-butanol demonstrated higher thermal efficiency as a result of combustion of higher fuel mass by volume. On the contrary, more n-butanol fraction leads to decrease thermal efficiency owing to lower heating value. So, it can be pointed out that 25BUT75HEP was seen to be the best fuel in view of engine performance and thermal efficiency.

Knocking and misfiring are the most important parameters which restrict the HCCI combustion. The fuels with high octane number can eliminate the knocking problem. Figure 7 represents the HCCI operating range for the test fuels versus engine speed.

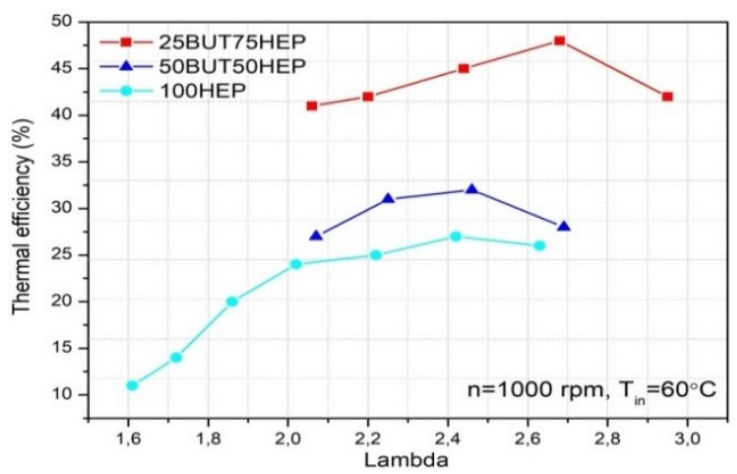

Figure 6 . The variation of thermal efficiency versus lambda

As it can be seen from the Figure 7 that HCCI combustion was achieved at misfiring zone for n-heptane. But HCCI combustion could not be obtained with 25BUT75HEP and 50BUT50HEP in a large misfiring zones. On the contrary, HCCI combustion could not be achieved with n-heptane in a large knocking zone. When the Figure 7 was examined, it is possible to say that HCCI combustion could be performed with the test fuels added n-butanol between 800 and $1800 \mathrm{rpm}$ engine speed. Besides, HCCI combustion could not be performed with n-heptane at $1800 \mathrm{rpm}$ engine speed. 25BUT75HEP presented larger region at partial combustion. 25BUT75HEP caused to improve complete auto igniton combustion. Stable HCCI combustion was achieved with 25BUT75HEP and 50BUT50HEP in misfiring zone. Namely, poorer charge mixture can be able to combust with the addition of n-butanol compared to n-heptane. N-butanol addition showed better performance in misfiring zone compared to knocking zone as seen in Figure 7. Broader operating range of HCCI was seen with fuel blends.

Figure 8 shows the variation of the $\mathrm{HC}$ and $\mathrm{CO}$ emissions versus lambda at $100 \mathrm{rpm}$ engine speed and $60{ }^{\circ} \mathrm{C}$ inlet air temperature. As it was mentioned above that HCCI combustion has low combustion temperatures. Low combustion temperature results insufficient oxidation of the fuel and cause high $\mathrm{HC}$ emission.

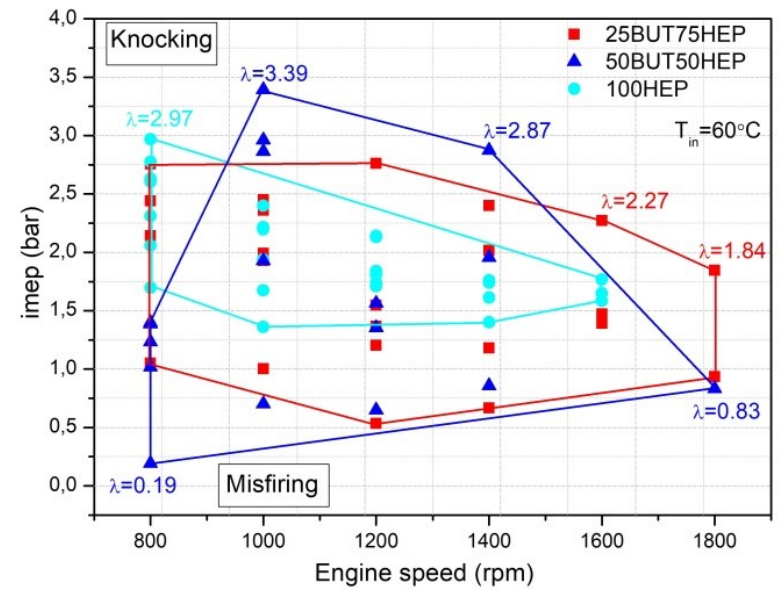

Figure 7. The variations of IMEP versus engine speed
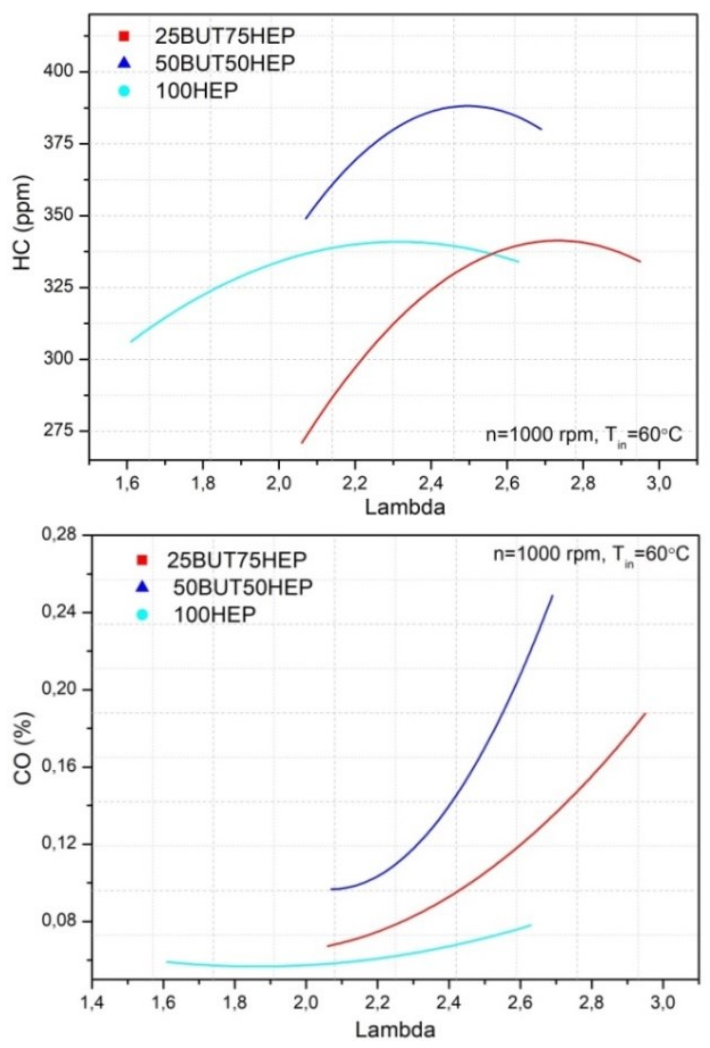

Figure 8. The variations of $\mathrm{HC}$ and $\mathrm{CO}$ emissions versus lambda

$\mathrm{HC}$ emission increased with increasing lambda for each test fuels. The amount of fuel taken into the cylinder decreases when the lambda 
increases and more incomplete combustion occurs. In the other words, in-cylinder pressure and combustion efficiency increases because more fuel is burned as the air/fuel mixture closes to the stoichiometric ratio. So, HC emission decreases. The HC emission was found as 349 , 341 and $388 \mathrm{ppm}$ for 100HEP, 25BUT75HEP and 50BUT50HEP, respectively, at $\lambda=2.4$. Incomplete combustion is the major effect which generates the $\mathrm{CO}$ emission. It is seen from the Figure 8 that $\mathrm{CO}$ emissions increased when the lambda increased since less amount of fuel was taken into the cylinder and more incomplete combustion occurred. $\mathrm{CO}$ emissions of 100HEP, 25BUT75HEP and 50BUT50HEP were obtained as $0.072,0.095$ and $0.153 \%$, respectively, at $\lambda=2.4$.

\section{Conclusions}

An investigation on the combustion, performance and emissions of $n$-butanol $/ \mathrm{n}$ heptane fuelled HCCI engine has been carried out at various engine speed and lambda values. Knocking combustion was observed for nheptane at rich mixtures but knocking disappeared when n-butanol was added into the mixture. Both in-cylinder pressure and heat release rate decreased with increasing of nbutanol in the mixture. Besides, CA10 was moved to ATDC from BTDC for 50BUT50HEP. The CA10 values of 100HEP, 25BUT75HEP and 50BUT50HEP were 6.58 ${ }^{\circ} \mathrm{CA}$ (BTDC), $1.8{ }^{\circ} \mathrm{CA}$ (ATDC) and $5.76^{\circ} \mathrm{CA}$ (ATDC) at $\lambda=2.4$. Ringing intensity decreased with increasing of lambda value. Power output and brake torque showed similar tendency, firstly increased and then decreased when reached to specific value. Thermal efficiency increased with increasing of lambda. 25BUT75HEP showed the maximum thermal efficiency compared to two other test fuels. 25BUT75HEP showed about 21\% higher thermal efficiency than 100HEP when the maximum values were compared. $\mathrm{CO}$ and $\mathrm{HC}$ emissions increased when the lambda increased. Furthermore, the addition of n-butanol into the mixture increased $\mathrm{HC}$ and $\mathrm{CO}$ emissions.

\section{Abbreviations}

HCCI : Homegeneous charge compression ignition

Imep : Indicated mean effective pressure
BTDC : Before top dead center

ATDC : After top dead center

EGR : Exhaust gas recirculation

\section{Nomenclature}

$\mathrm{W}_{\text {net }} \quad$ : Net work

$\mathrm{V}_{\mathrm{d}} \quad$ : Cylinder swept volume

$\mathrm{P} \quad$ : Cylinder pressure

$\mathrm{dV} \quad$ : Variation of cylinder volume

$d Q \quad:$ Heat release

$d \theta \quad$ : Crank angle

$\mathrm{m}_{\text {fuel }}$ : Consumed fuel per cycle

$\mathrm{Q}_{\mathrm{LVH}}$ : Heating value of the fuel

\section{References}

1. Gul, Z., M. Yilmaz, H. Koten, I. H., Savc1, "Advanced Numerical and experimental studies on CI engine emissions", Journal of Thermal Engineering, 4 (4), 2234-2247, 2018.

2. Strozzi, C., Claverie, A., Prevost, V., Sotton, J., and Bellenoue, M., "HCCI and SICI combustion modes analysis with simultaneous PLIF imaging of formaldehyde and high-speed chemiluminescence in a rapid compression machine", Combustion and Flame, 202, 58-77, 2019.

3. Maurya, R.K. and Akhil, N., "Development of a new reduced hydrogen combustion mechanism with $\mathrm{NO}_{\mathrm{x}}$ and parametric study of hydrogen HCCI combustion using stochastic reactor model". Energy Conversion and Management, 132: 65-81, 2017. 4. Kumar, P. and Rehman A., "Bio-diesel in homogeneous charge compression ignition (HCCI) combustion", Renewable and Sustainable Energy Reviews, 56, 536-550, 2016.

5. Wang, Z., Du, G., Li, Z., Wang, X., and Wang, D., "Study on the combustion characteristics of a high compression ratio HCCI engine fueled with natural gas", Fuel, 255, 115701, 2019.

6. Vélez Godiño, J.A., Jiménez-Espadafor Aguilar F.J., and García M.T., "Simulation of HCCI combustion in air-cooled off-road engines fuelled with diesel and biodiesel", Journal of the Energy Institute, 91(4), 549-562, 2018.

7. Cinar, C., Uyumaz, A., Solmaz, H., Sahin, F., Polat, S., Y1lmaz, E., "Effects of intake air temperature on combustion, performance and emission characteristics of a 
HCCI engine fueled with the blends of $20 \% \mathrm{n}$ heptane and $80 \%$ isooctane fuels", Fuel Processing Technology, 130, 275-281, 2015.

8. Garcia, M.T., Aguilar, F., Lancero, T.S., and Villanueva, J.A.B., "A new heat release rate (HRR) law for homogeneous charge compression ignition (HCCI) combustion mode", Applied Thermal Engineering, 29(1718), 3654-3662, 2009.

9. $\quad$ Bai, J., Wang, Q., H.E, Z., Li, C., and Pan, J., "Study on methane HCCI combustion process of micro free-piston power device", Applied Thermal Engineering, 73(1), 10661075, 2014.

10. Turkcan, A., Ozsezen A.N., and Canakci M., "Effects of second injection timing on combustion characteristics of a two stage direct injection gasoline-alcohol HCCI engine", Fuel, 111: 30-39, 2013.

11. Schönborn, A., Hellier, P., Aliev, A.E., "Ignition control of homogeneous-charge compression ignition (HCCI) combustion through adaptation of the fuel molecular structure by reaction with ozone", Fuel, 89 (11), 3178-3184, 2010.

12. Zhang, C., Zhang, C., Xue, L., Li, Y., "Combustion characteristics and operation range of a RCCI combustion engine fueled with direct injection n-heptane and pipe injection nbutanol", Energy, 125, 439-448, 2017.

13. Bahri, B., Aziz, A. A., Shahbakhti, M., and Muhamad Said, M.F., "Understanding and detecting misfire in an HCCI engine fuelled with ethanol", Applied Energy, 108, 24-33, 2013.

14. Bastawissi, H.A.E., Elkelawy, M., PAnchal, H., and Kumar Sadasivuni, K., "Optimization of the multi-carburant dose as an energy source for the application of the HCCI engine", Fuel, 253, 15-24, 2019.

15. Gharehghani, A., "Load limits of an HCCI engine fueled with natural gas, ethanol, and methano", Fuel, 239, 1001-1014, 2019.

16. Bhaduri, S., H. Jeanmart, and F. Contino, "Tar Tolerant HCCI Engine Fuelled with Biomass Syngas: Combustion Control Through EGR", Energy Procedia, 105, 17641770, 2017.

17. Putrasari, Y., N. Jamsran, and O. Lim, "An investigation on the DME HCCI autoignition under EGR and boosted operation", Fuel, 200, 447-457, 2017.
18. Sjöberg, M. and J.E. Dec," Effects of EGR and its constituents on HCCI autoignition of ethanol", Proceedings of the Combustion Institute, 33(2), 3031-3038, 2011.

19. Cinar, C., Uyumaz, A., Solmaz, G., Topgul, T., "Effects of valve lift on the combustion and emissions of a HCCI gasoline engine", Energy Conversion and Management, 94, 159-168, 2015.

20. Çınar, C., Uyumaz A., Polat, S., Yılmaz, E., Can, O., and Solmaz, H., "Combustion and performance characteristics of an HCCI engine utilizing trapped residual gas via reduced valve lift", Applied Thermal Engineering, 100, 586594, 2016.

21. Gowthaman, S. and A.P. Sathiyagnanam, "Effects of charge temperature and fuel injection pressure on HCCI engine", Alexandria Engineering Journal, 55(1), 119$125,2016$.

22. Gowthaman, S. and A.P. Sathiyagnanam, "Analysis the optimum inlet air temperature for controlling homogeneous charge compression ignition (HCCI) engine", Alexandria Engineering Journal, 57(4), 22092214, 2018.

23. Koten, H., M. Y1lmaz, Z. Gul, "Effects of the injection parameters and compression ratio on the emissions of a heavy-duty diesel engnie", International Journal of Vehicle Design, 59(2/3), 147-163, 2012.

24. Mathivanan, K., J.M. Mallikarjuna, and A. Ramesh, "Influence of multiple fuel injection strategies on performance and combustion characteristics of a diesel fuelled HCCI engine An experimental investigation", Experimental Thermal and Fluid Science, 77, 337-346, 2016. 25. Banke, K., Hegner, R., Scröder, D., Schulz, C., Atakan, B., and Kaiser, S.A., "Power and syngas production from partial oxidation of fuel-rich methane/DME mixtures in an HCCI engine", Fuel, 243, 97-103, 2019.

26. Bendu, H., B.B.V.L. Deepak, and S. Murugan, "Multi-objective optimization of ethanol fuelled HCCI engine performance using hybrid GRNN-PSO”, Applied Energy, 187, 601-611, 2017.

27. Coskun, G., Demir, E., Soyhan, H. S., Turkcan, A., Ozsezen, A.N., and CAnakc1, M., "An experimental and modeling study to investigate effects of different injection parameters on a direct injection HCCI 
combustion fueled with ethanol-gasoline fuel blends", Fuel, 215, 879-891, 2018.

28. Turkcan, A., Altınkurt, M.D., Csokun, G., and Canakc1, M., "Numerical and experimental investigations of the effects of the second injection timing and alcohol-gasoline fuel blends on combustion and emissions of an HCCI-DI engine", Fuel, 219, 50-61, 2018.

29. Wang, Z., Liu, H., Ma, X., WAng, J., Shuai, S., and Reitz, R.D., "Homogeneous charge compression ignition (HCCI) combustion of polyoxymethylene dimethyl ethers (PODE)", Fuel, 183, 206-213, 2016.

30. Maurya, R.K. and N. Akhil, "Numerical investigation of ethanol fuelled HCCI engine using stochastic reactor model. Part 1: Development of a new reduced ethanol oxidation mechanism", Energy Conversion and Management, 118, 44-54, 2016.

31. Viggiano, A. and V. Magi, "A comprehensive investigation on the emissions of ethanol HCCI engines", Applied Energy, 93, 277-287, 2012.

32. Chun-hua, Z., Jiang-ru, P.A.N., Juanjuan, T., and Jing, L.I., "Effects of Intake Temperature and Excessive Air Coefficient on Combustion Characteristics and Emissions of HCCI Combustion", Procedia Environmental Sciences, 11, 1119-1127, 2011.

33. Yousefi, A. and M. Birouk, "Fuel suitability for homogeneous charge compression ignition combustion", Energy Conversion and Management, 119, 304-315, 2016.

34. Polat, S., "An experimental study on combustion, engine performance and exhaust emissions in a HCCI engine fuelled with diethyl ether-ethanol fuel blends", Fuel Processing Technology, 143, 140-150, 2016.

35. Mohebbi, M., Reyhanian, M., Hosseini, V., Said, M.F.M., and Aziz, A.A., "The effect of diethyl ether addition on performance and emission of a reactivity controlled compression ignition engine fueled with ethanol and diesel", Energy Conversion and Management, 174, 779792, 2018.

36. Khandal, S.V., N.R. Banapurmath, and V.N. Gaitonde, "Performance studies on homogeneous charge compression ignition (HCCI) engine powered with alternative fuels", Renewable Energy, 132, 683-693, 2019.

37. Maurya, R.K. and M.R. Saxena,
"Characterization of ringing intensity in a hydrogen-fueled HCCI engine", International Journal of Hydrogen Energy, 43(19), 94239437, 2018.

38. He, B.Q., Liu, M.B., Yuan, J., and Zhao, H., "Combustion and emission characteristics of a HCCI engine fuelled with n-butanol-gasoline blends", Fuel, 108, 668-674, 2013.

39. Li, G., C. Zhang, and J. Zhou, "Study on the knock tendency and cyclical variations of a HCCI engine fueled with n-butanol/n-heptane blends", Energy Conversion and Management, 133, 548-557, 2017.

40. Liu, M.-B., B.-Q. He, and H. Zhao, "Effect of air dilution and effective compression ratio on the combustion characteristics of a HCCI (homogeneous charge compression ignition) engine fuelled with n-butanol", Energy, 85, 296-303, 2015.

41. Zheng, M., Han, X., Asad, U., and Wang, J., "Investigation of butanol-fuelled HCCI combustion on a high efficiency diesel engine", Energy Conversion and Management, 98, 215-224, 2015.

42. Mack, J.H., Shuler, D., Butt, R.H., and Dibble R.W., "Experimental investigation of butanol isomer combustion in Homogenous Charge Compression Ignition (HCCI) engines", Applied Energy, 165, 612-626, 2016.

43. He, B., Liu, M., and Zhao, H., "Comparison of combustion characteristics of n-butanol/ethanol-gasoline blends in a HCCI engine", Energy Conversion and Management, 95, 101-109, 2015.

44. Uyumaz, A., "An experimental investigation into combustion and performance characteristics of an HCCI gasoline engine fueled with n-heptane, isopropanol and nbutanol fuel blends at different inlet air temperatures", Energy Conversion and Management, 98, 199-207, 2015.

45. Kodavasal, J., Lovoie, G., A., Assanis, D.N., and Martz, J.B., "The effects of thermal and compositional stratification on the ignition and duration of homogeneous charge compression ignition combustion", Combustion and Flame, 162(2), 451-461, 2015.

46. Johansson, T., Joqahnsson, B., Tunestal, P. And Hans, A., "HCCI Operating Range in a Turbo-charged Multi Cylinder Engine with VVT and Spray-Guided DI", SAE paper, 200901-0494, 2009. 
47. Lee, K., Cho, S., Kim, N., and Min, K., "A study on combustion control and operating range expansion of gasoline HCCI", Energy, 91, 1038-1048, 2015. 